\title{
ОСОБЛИВОСТІ ЖІНОЧОГО БАЛЕТНОГО ВИКОНАВСТВА 1970-1980-Х РР. (НА ПРИКЛАДІ СЦЕНІЧНОЇ ДІЯЛЬНОСТІ Т. ЛИТВИНОВОЇ ТА С. ПРИХОДЬКО)
}

\section{Ольга Верховенко}

кандидат мистецтвознавства;

e-mail: olenkaverkhovenko.25@gmail.com; ORCID: 0000-0001-5063-3306

Національний університет фізичного виховання і спорту України, Київ, Україна

\begin{abstract}
Анотація
Мета дослідження - вивчити сценічні здобутки провідних солісток столичної балетної сцени Тетяни Литвинової та Світлани Приходько, які успішно працювали на сцені Київського ДАТОБ ім. Т. Шевченка впродовж 1970-1980-х років. Методологія роботи базується на таких методах дослідження: загальноісторичному (з метою вивчення історичних процесів, що відбувалися в мистецькому середовищі України впродовж останньої чверті XX ст.), історико-культурному (дає змогу дослідити динаміку розвитку виконавської культури танцівників), аналітичному (для опрацювання історіографічних джерел - культурологічної, мистецтвознавчої та театрознавчої літератури), системному (для систематизації відомостей щодо творчого становлення артистів Київського ДАТОБ ім. Т. Шевченка) та ін. Наукова новизна публікації полягає в тому, що в ній уперше розглянуто творчі доробки Т. Литвинової та С. Приходько, пов'язані з їх участю в новаторських постановках балетмейстерів останньої чверті XX століття. Висновки. ШляХ у велике мистецтво для Т. Литвинової та С. Приходько відкрився на початку 1970-х рр. з приходом у балетну трупу Київського ДАТОБ ім. Т. Шевченка. Там до кінця 1980-х рр. вони творили під орудою провідних балетмейстерів того часу: А. Шекери, Г. Майорова, В. Литвинова та інших постановників. Виконавчій манері обох балерин були однаково близькими як ліричні образи (поезія романтичного світу - Одетта-Оділія, Жізель, Мірта, Біла Дама, Сильфіда, Польова русалка), так і партії, сповнені глибокого драматичного звучання (суперечливий світ людських пристрастей - Кармен, Ольга, Ширін, Фрігія, Зарема, Дівчина). До числа особливих сценічних перемог танцівниць увійшли престижні премії II Міжнародного конкурсу артистів балету в Москві, Х Всесвітнього фестивалю молоді і студентів у Берліні (Т. Литвинова), Всесоюзного конкурсу балетмейстерів та артистів балету в Москві (С. Приходько).
\end{abstract}

Ключові слова: Т. Литвинова; С. Приходько; український балетний театр; класичний танець

\section{Постановка проблеми}

1970-1980-ті рр. увійшли в історію вітчизняного балетного мистецтва як період художнього новаторства не лише в руслі композиторських і балетмейстерських шукань, а й у площині виконавської творчості. Саме в цей відрізок часу 
Вісник Київського національного університету культури і мистецтв.

Серія: Сценічне мистецтво

з'явилося чимало балетних творів українських композиторів, наповнених оригінальним симфонічним змістом («Ольга», «Прометей» $Є$. Станковича, «Фантастична симфонія» Г. Берліоза, «Спартак» А. Хачатуряна, «Чіполліно» К. Хачатуряна, «Дівчина і Смерть» Г. Жуковського та ін.). Сценічна реалізація останніх відбулася завдяки прагненню балетмейстерів-експериментаторів (А. Шекери, Г. Майорова, В. Литвинова, В. Федотова та ін.) віднайти влучні образні рішення та пластичні вислови. Не останню роль у цьому відіграла фахова діяльність балетних артистів, зокрема провідних солісток, що працювали на сцені Київського державного академічного театру опери та балету ім. Т. Шевченка (далі - Київський ДАТОБ ім. Т. Шевченка). У цьому контексті варто насамперед згадати постаті відомих танцівниць театру, які працювали впродовж 1970-1980-х років. Серед них представниці старшого покоління (В. Калиновська, А. Лагода, Н. Руденко, Л. Сморгачова, Е. Стебляк, Н. Уманова) і талановита молодь (Р. Хілько, Т. Таякіна, Г. Кушнірова, Т. Боровик, Т. Білецька, І. Задаянна), творчість яких позначилася появою яскравої галереї нових і добре відомих балетних образів.

Поважне місце серед виконавців 1970-1980-х рр. посіли творчі постаті балерин Тетяни Литвинової та Світлани Приходько, персоналії яких, на жаль, тривалий час залишалися маловідомими для сучасного покоління українських мистецтвознавців.

\section{Аналіз останніх досліджень і публікацій}

Заявлену в статті тематику - особливості жіночого балетного виконавства Київського ДАТОБ ім. Т. Шевченка 1970-1980-х рр. - неодноразово обговорювали сучасні українські дослідники, зокрема В. Захарова (2018, с.268-273), А. Підлипська (2018, с.314-317), Н. Семенова (2012, с.189-198), які відтворили панораму спадкоємності мистецьких поколінь, визначили стилістичні маркери в балетному виконавстві артисток Київського ДАТОБ ім. Т. Шевченка; систематизували творчий добуток жінок - танцівниць, педагогів, балетмейстерів, висвітлили їхню роль у становленні вітчизняної школи балету; проаналізували хореографічні образи, створені українськими балеринами, зокрема, розглянули пластичне втілення окремих партій. Заразом постаті Т. Литвинової та С. Приходько залишалися поза колом наукових зацікавлень вітчизняних мистецтвознавців. Згадку про балерин можна найти лише в монографіях Ю. Станішевського, таких як «Балетний театр України: 225 років історії» (2003), «Національний академічний театр опери та балету України імені Тараса Шевченка: історія і сучасність» (2002), та довіднику, укладеному В. Туркевичем, «Хореографічне мистецтво України в персоналіях» (1999).

Джерелом для підготовки цієї публікації стали відгуки й рецензії радянських театрознавців на події культурного життя Києва 1970-1980-х рр. - М. Кухарчука (1982, с.6-7), М. Варзацької (1987, с.10-12), а також коментарі та спогади педагогів-репетиторів, які працювали з Т. Литвиновою та С. Приходько (Лукашова, 1977, с.11-12; Стебляк, 2000).

Мета роботи полягає у вивченні сценічних здобутків провідних солісток столичної балетної сцени - Тетяни Литвинової та Світлани Приходько, які успішно працювали на сцені Київського ДАТОБ ім. Т. Шевченка впродовж 1970-1980-х років. 


\section{Виклад основного матеріалу}

Заслужена артистка України Тетяна Литвинова (дів. Чередниченко) народилася 1948 р. у Донецьку. Балету почала навчатися в ранньому дитинстві у місцевому центрі дитячого дозвілля - Палаці піонерів. Чудові природні дані дали змогу Т. Литвиновій вступити до Київського хореографічного училища, де вона здобула фахову хореографічну освіту.

Одразу після закінчення спеціалізованого осередку в 1967 р. Т. Литвинова повернулася на малу Батьківщину - у Донецький ДАТОБ, однак протанцювала на його сцені лише рік. 1968 р. вона виїхала в Москву, де потрапила до складу Державного хореографічного концертного ансамблю «Молодий балет» під керівництвом Ігоря Моїсєєва (тепер - Державний академічний ансамбль народного танцю імені І. Моїсєєва). Там артистка набула цінного практичного досвіду сценічної роботи з відомими у СРСР педагогами й балетмейстерами - А. Мессерером, І. Моїсєєвим, К. Голейзовським та іншими діячами хореографічного мистецтва. Заняття під їх керівництвом сприяли професійному зростанню балерини, стимулювали її на самостійні творчі пошуки.

1971 р. Т. Литвинова повернулася в Україну, де пройшла відбір до балетної трупи Київського ДАТОБ ім. Т. Шевченка. Розпочавши творчий шлях у кордебалеті, вона під орудою досвідченого педагога-репетитора І. Лукашової досить швидко опанувала сольні партії. Першою провідною роллю для неї стала Фея Бузку в «Сплячій красуні» П. Чайковського. Після неї до репертуару артистки ввійшли й інші образи: Жізель, Мірта («Жізель» А. Адана), Кітрі («Дон Кіхот» Л. Мінкуса), Сильфіда (однойменна вистава Х. Левенсхольда), Біла Дама («Раймонда» О. Глазунова), Польова русалка («Лісова пісня» М. Скорульського), Ольга (однойменна вистава $€$. Станковича), Магнолія («Чіполліно» К. Хачатуряна), Королева-мачуха («Білосніжка та семеро гномів» Б. Павловського) та інші партії. За визначенням В. Туркевича (1999, с.122), виконавську манеру артистки вирізняли «академічна строгість, чистота арабеску та надзвичайна пластичність». М. Кухарчук (1982, с.7) наголошував на лірико-романтичній спрямованості сценічних утілень Т. Литвинової, яка реалізовувалася завдяки «вишуканій красі арабесків, атитюдів, жете».

Однією з найкращих сценічних робіт артистки стала партія Одетти-Оділії в «Лебединому озері» П. Чайковського (рис. 1), виконання якої засвідчило високий фаховий рівень зрілості Т. Литвинової як митця, який глибоко розуміє сутність академічної хореографії (з невеликими перервами, артистка готувала партію Одетти-Оділії два з половиною роки). І. Лукашова - педагог-репетитор Т. Литвинової - наголошувала, що класична хореографія $€$ досить близькою танцівниці завдяки наявності в неї прекрасних технічних даних. Адже Т. Литвинова (1977, с.12) мала високий стрибок, стійкі обертання, виразні дрібні пуантові рухи (наприклад, «бісерні па де бурре»), видовжену плавність ліній, надзвичайно кантиленну пластику рук, музичність і чудову акторську зануреність в образ. І. Лукашова, зокрема, зазначала:

«Мені довелося працювати з нею [Т. Литвиновою - авт.] над образом Одетти-Оділії, і хочеться сказати, що це були не просто репетиції, а щоденний, щохвилинний пошук штрихів, які б надали партії лірич- 
ності, поетичності, глибокої внутрішньої піднесеності... У всьому відчувалося, що балерина не просто прагнула розширити свій репертуар, а й самовиразитися, добитися того, щоб партія зазвучала в усій красі і глибині». (Ніжна трепетність Одетти, 1977, с. 12)

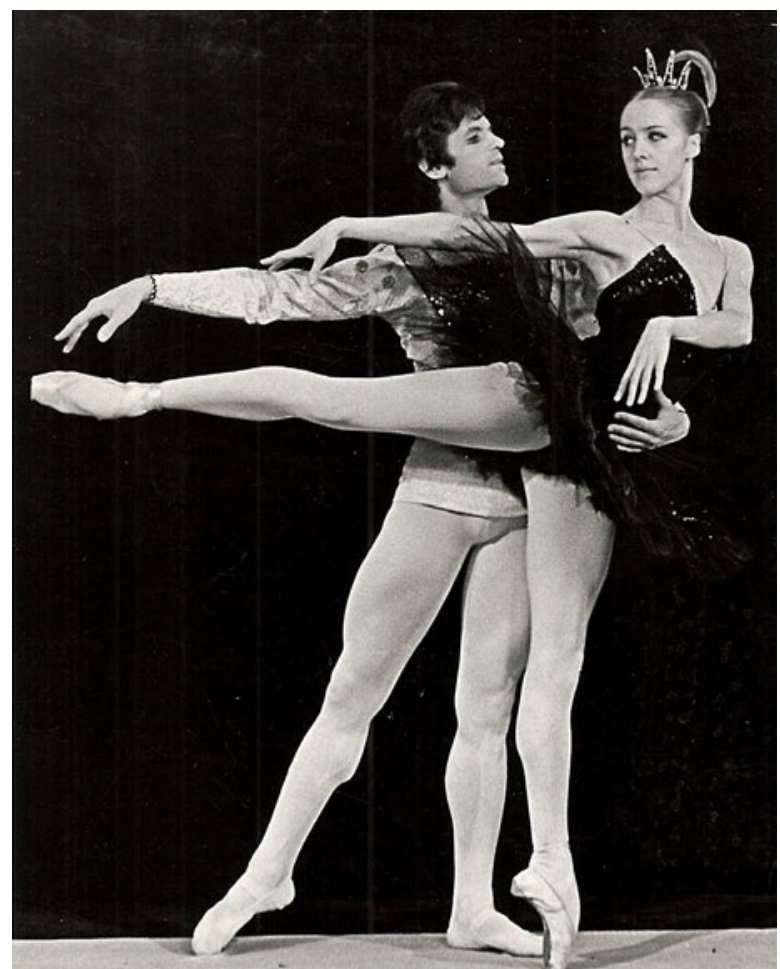

Рис. 1. Микола Прядченко, Тетяна Литвинова. «Лебедине озеро»'

Радянські театрознавці, які мали змогу спостерігати за Т. Литвиновою в цій партії, так само відзначали, що образ розкривався у виконанні балерини, немов «романтична поема». Оскільки в окремих епізодах солістка трагедійно загострювала його, в інших - пом'якшувала, нагадуючи Вмираючого лебедя зі славнозвісної постановки М. Фокіна. Вона змогла передати на сцені, з одного боку, ніжність і трепетність своєї героїні, з іншого - зберегти в ній ту казковість, яка надавала глядачу змогу відчути кордон між реальністю та поезією небуденності (Кухарчук, 1982, с.7).

Надзвичайне враження справляла артистка в лірико-драматичних партіях, таких як Дівчина («Світанкова поема» В. Косенка), Фрігія («Спартак» А. Хачатуряна), Ширін («Легенда про любов» А. Мелікова). Уже згадуваний М. Кухарчук $(1982$, с.7) писав про драматичні здібності Т. Литвинової: «Акторська гра

\footnotetext{
1 Фотографії у статті з архіву Національної опери України.
} 
Тетяни - лаконічна й, водночас, виразна, емоційно наснажена - позначена благородством і стриманістю у вияві почуттів, романтичною одухотвореністю, завдяки чому її героїні сприймаються як неординарні особистості з глибоким і своєрідним внутрішнім світом». Мистецтвознавець також підкреслював, що легка, граційна й витончена, балерина завжди була помітною на сцені, навіть у невеликих епізодичних ролях. Іїі мистецтво хвилювало глядача, наповнювало високим естетичним почуттям, вабило багатством і красою танцювальної лексики, чарівною «лебединою» пластикою, яка надавала виконавській манері танцівниці своєрідного колориту (Кухарчук, 1982, с.6).

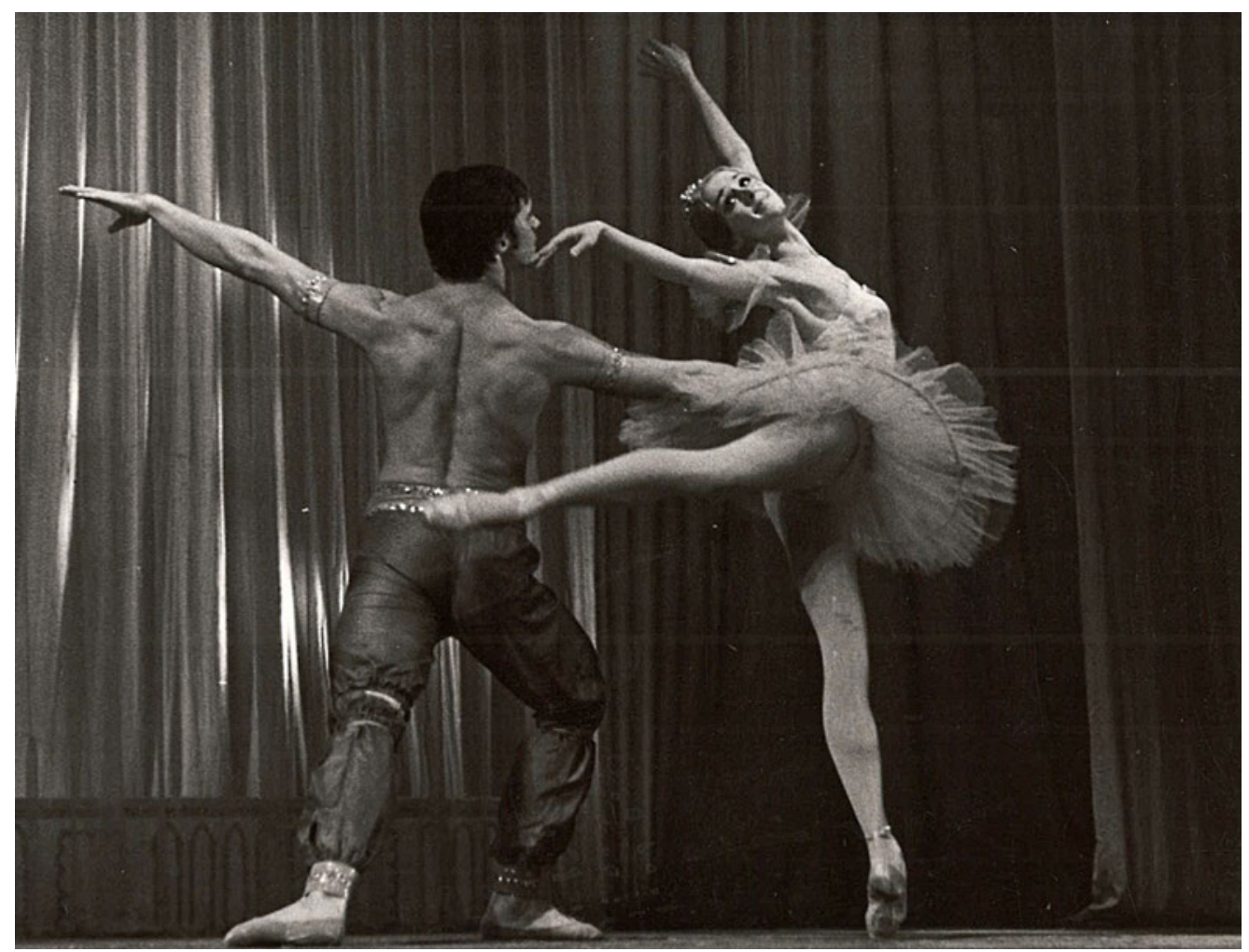

Рис. 2. Віктор і Тетяна Литвинови. «Корсар», концерт, 1973 р.

1973 р. Т. Литвинова взяла участь у II Міжнародному конкурсі артистів балету в Москві, де посіла третє місце та здобула бронзову медаль хореографічного змагання (рис. 2, 3). Успіх спрямував балерину до участі в балетному конкурсіфестивалі, який відбувся в межах X Всесвітнього фестивалю молоді і студентів у Берліні (Німеччина).

Після закінчення сценічної кар'єри в 1991 р. Т. Литвинова перейшла на балетмейстерсько-репетиторську роботу в трупу «Павлова-Ніжинський меморіал інтернешенел де Очі» (Японія), згодом працювала в танцювальних колективах у США та Канаді. 


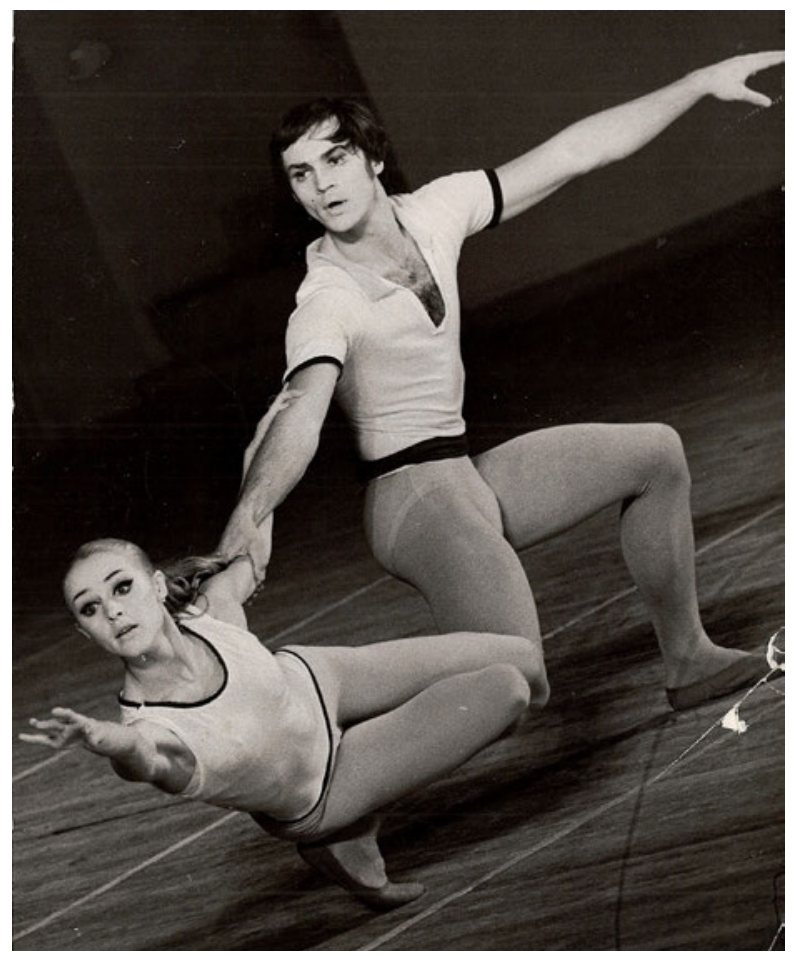

Рис. 3. Віктор і Тетяна Литвинови. Хореографічна мініатюра «Голубі далі», хореограф Генріх Майоров, 1973 р.

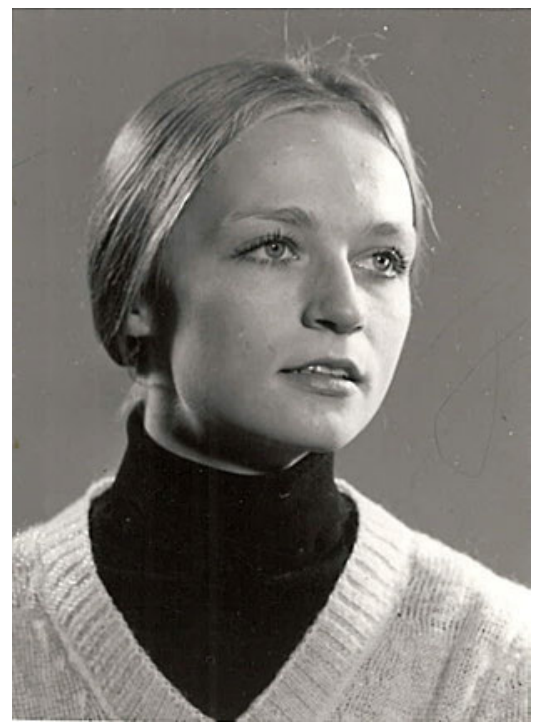

Рис. 4. Світлана Приходько
Майже одночасно з приходом до Київського ДАТОБ ім. Т. Шевченка Т. Литвинової свою сценічну кар'єру в театрі розпочала інша балерина - Світлана Приходько (нар. 1955 р.) (рис. 4). 1972 р., після закінчення Київського хореографічного училища (диплом з відзнакою), артистка вступила до балетної трупи, де як початківець традиційно розпочала шлях у велике мистецтво з кордебалету. Поштовхом для подальшого розвитку творчої кар'єри С. Приходько стала її участь у Всесоюзному конкурсі балетмейстерів та артистів балету в Москві, де в парі з В. Федорченком вона продемонструвала високий рівень професійної підготовки в концертному номері «Журавлі». Лейтмотивом останнього стала «поетична одухотвореність, одвічне прагнення польоту, мрія про красу й гармонію життя» (Варзацька, 1987, с.10). 


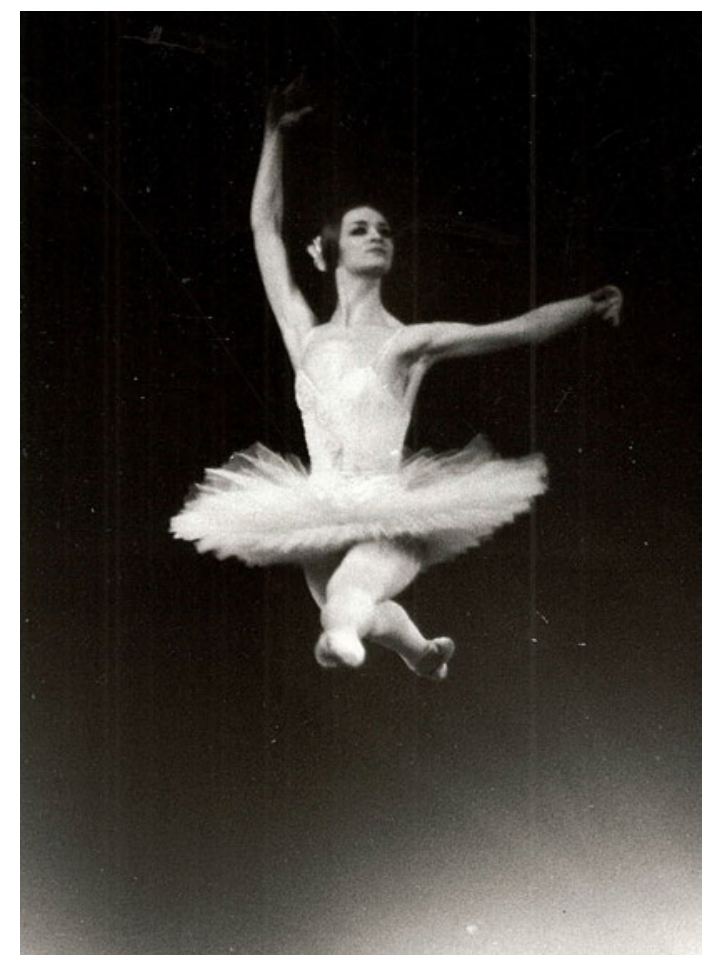

Рис. 5. Світлана Приходько

Поступово С. Приходько набувала досвіду в сольних партіях (рис. 5). Успіху на балетній сцені багато в чому сприяла ії робота з досвідченим педагогомрепетитором Е. Стебляк. Саме з нею солістка підготувала ролі Цариці в «Прометеї» $€$. Станковича, Одетти-Оділії в «Лебединому озері» П. Чайковського, Дівчини в білому в «Болеро» М. Равеля. 3 приводу останньої партії зазначимо, що сам постановник досить критично поставився до сценічної роботи балерини. Е. Стебляк (дружина А. Шекери) пригадувала: «Як тільки він [А. Шекера - авт.] закінчував роботу - повністю втрачав до неї інтерес... Років п'ять не могла його вмовити подивитися хоча б на виконавицю Світлану Приходько - чудову, як лебедиця. I коли все-таки подивився, підійшов до балерини зі словами: "З ненавістю - відмінно, кохання - ніякого!"» (Поліщук, 2000).

Радянські мистецтвознавці (Ю. Станішевський, М. Варзацька) наголошували, що на сцені С. Приходько демонструвала, з одного боку, яскраве лірико-романтичне обдарування (головні героїні в однойменних балетах «Жізель» А. Адана, «Сильфіда» Х. Левенсхольда), з іншого - вражала проникливим драматизмом (головні ролі в однойменних балетах «Кармен-сюїта» Ж. Бізе - Р. Щедріна, «Ольга» $Є$. Станковича, а також Зарема в «Бахчисарайському фонтані» Б. Асаф'єва та Мехмене Бану в «Легенді про любов» А. Мелікова). Дійсно, С. Приходько могла одночасно хвилювати як благородством ліній, грацією рухів, поетичністю та надзвичайною музикальністю, так і вражати глибиною драматизму, тонкою інтерпретацією нео- 
класичного хореографічного репертуару. Мистецтвознавець М. Варзацька писала про неї, що творча індивідуальність балерини яскраво виявлялася в умінні проникливо, художньо глибоко змальовувати своїх героїв. Дослідниця зазначала: «Напрочуд тонко передає вона елегійну печаль Вмираючого лебедя... Вражає холодна велич її Мірти, котра залишається в пам'яті символом фантастичного світу віліс... І зовсім протилежна гама почуттів - Фея Бузку, ця добра чарівниця, котра, мов любляча мати своїх дітей, піклується про казкових персонажів "Сплячої красуні"» (Варзацька, 1987, с.12).

Одне з особливих місць у репертуарі танцівниці посіла партія Ольги з однойменного балету $€$. Станковича. Балерина так пояснювала власне ставлення до цього образу: «Для мене головне в балеті - показати особистість, людину складну, з багатим духовним життям, мислячу, хай навіть суперечливу. У моєму репертуарі, чесно кажучи, мені мало що по-справжньому подобається. Єдина роль, в якій я вперше в житті змогла висловитись, - Ольга» (Варзацька, 1987, с.11). Варто зазначити, що С. Приходько пощастило виконувати головну партію в «Ользі» саме на прем'єрному показі в 1982 році. Хореографія балетмейстера А. Шекери допомогла балерині втілити на сцені багатогранний світ сильної жінки, історія життя якої стала поєднанням щастя любові та трагедії розлуки, радістю і відчаєм материнства.

Після закінчення сценічної кар'єри С. Приходько на початку 1990-х рр. перейшла на педагогічну та репетиторську діяльність: працювала в драматичних трупах Києва, зокрема з 1995 р. в Національному академічному театрі російської драми ім. Лесі Українки.

Наукова новизна публікації полягає в тому, що в ній уперше розглянуто творчі доробки Т. Литвинової та С. Приходько, пов'язані з їх участю у новаторських постановках балетмейстерів останньої чверті XX століття.

\section{Висновки}

Шлях у велике мистецтво для Т. Литвинової та С. Приходько відкрився на початку 1970-х рр. з приходом у балетну трупу Київського ДАТОБ ім. Т. Шевченка. Там до кінця 1980-х рр. вони творили під орудою провідних балетмейстерів того часу: А. Шекери, Г. Майорова, В. Литвинова та інших постановників. Виконавчій манері обох балерин були однаково близькими як ліричні образи (поезія романтичного світу - Одетта-Оділія, Жізель, Мірта, Біла Дама, Сильфіда, Польова русалка), так і партії, сповнені глибокого драматичного звучання (суперечливий світ людських пристрастей - Кармен, Ольга, Ширін, Фрігія, Зарема, Дівчина). До числа особливих сценічних перемог танцівниць увійшли престижні премії II Міжнародного конкурсу артистів балету в Москві, X Всесвітнього фестивалю молоді і студентів у Берліні (Т. Литвинова), Всесоюзного конкурсу балетмейстерів та артистів балету в Москві (С. Приходько).

Звернення до творчого доробку видатних українських танцівниць Т. Литвинової та С. Приходько - це лише перша спроба окреслити їх внесок у розвиток вітчизняної та світової хореографії. Безумовним вектором подальших досліджень може стати як поглиблене вивчення виконавської майстерності балерин, так і їхня балетмейстерсько-репетиторська та викладацька діяльність. 


\section{СПИСОК ПОСИЛАНЬ}

Варзацька, М., 1987. Поліфонія почуттів. Театрально-концертний Київ, 2, с. 10-12. Захарова, В., 2018. Регіональний аналіз жіночого виконавства в українському балеті: 90-ті роки XX - початок XXI ст. (частина I: Київ і Львів). Культура і сучасність, 1, с.268-273. Кухарчук, М., 1982. Квітне цілою гамою барв. Театрально-концертний Київ, 5, с.6-7. Ніжна трепетність Одетти, 1977. Інтерв'ю з педагогом-репетитором І. Лукашовою. Театрально-концертний Київ, 12, с.11-12.

Підлипська, А., 2018. Школа жіночого балетного виконавства в Національній опері України ім. Т. Г. Шевченка. Вісник Національної академії керівних кадрів культури і мистецтв, 4, c.314-317.

Поліщук, Т., 2000. Останній з могікан українського балету. День, [online] 7 квітня. Доступно: <https://m.day.kyiv.ua/uk/article/panorama-dnya/ostanniy-iz-mogikan-ukrayinskogo-baletu> [Дата звернення 6 квітня 2021].

Семенова, Н., 2012. Особливості втілення видатними українськими балеринами хореографічних образів національних балетних вистав XX ст. Культура України, 39, c.189-198.

Станішевський, Ю., 2002. Національний академічний театр опери та балету України імені Тараса Шевченка: історія і сучасність. Київ: Музична Україна.

Станішевський, Ю., 2003. Балетний театр України: 225 років історії. Київ: Музична Україна. Туркевич, В., 1999. Хореографічне мистецтво України в персоналіях. Київ: Інтеграл.

\section{REFERENCES}

Kukharchuk, M., 1982. Kvitne tsiloiu hamoiu barv [Blooms a range of colors]. Teatralno-kontsertnyi Kyiv, 5, pp.6-7.

Nizhna trepetnist Odetty, 1977. Interviu z pedahohom-repetytorom I. Lukashovoiu [Interview with tutor I. Lukashova]. Teatralno-kontsertnyi Kyiv, 12, pp.11-12.

Pidlypska, A., 2018. Shkola zhinochoho baletnoho vykonavstva v Natsionalnii operi Ukrainy im. T. H. Shevchenka [School of female ballet performance at the National Opera of Ukraine. TG Shevchenko]. National Academy of Managerial Staff of Culture and Arts Herald, 4, pp.314-317. Polishchuk, T., 2000. Ostannii z mohikan ukrainskoho baletu [The last of the Mohicans of Ukrainian balle]. Den, [online] 7 April. Available at: <https://m.day.kyiv.ua/uk/article/panoramadnya/ostanniy-iz-mogikan-ukrayinskogo-baletu> [Accessed 6 April 2021].

Semenova, N., 2012. Osoblyvosti vtilennia vydatnymy ukrainskymy balerynamy khoreohrafichnykh obraziv natsionalnykh baletnykh vystav $X X$ st. [Features of the embodiment of outstanding Ukrainian ballerinas choreographic images of national ballet performances of the twentieth century]. Kultura Ukrainy, 39, pp.189-198.

Stanishevskyi, Yu., 2002. Natsionalnyi akademichnyi teatr opery ta baletu Ukrainy imeni Tarasa Shevchenka: istoriia i suchasnist [Taras Shevchenko National Academic Opera and Ballet Theater of Ukraine: history and modernity]. Kyiv: Muzychna Ukraina.

Stanishevskyi, Yu., 2003. Baletnyi teatr Ukrainy: 225 rokiv istorii [Ballet Theater of Ukraine: 225 years of history]. Kyiv: Muzychna Ukraina.

Turkevych, V., 1999. Khoreohrafichne mystetstvo Ukrainy $v$ personaliiakh [Choreographic art of Ukraine in personalities]. Kyiv: Intehral. 
Varzatska, M., 1987. Polifoniia pochuttiv [Polyphony of feelings]. Teatralno-kontsertnyi Kyiv, 2, pp.10-12.

Zakharova, V., 2018. Rehionalnyi analiz zhinochoho vykonavstva v ukrainskomu baleti: 90-ti roky XX - pochatok XXI st. (chastyna I: Kyiv i Lviv) [Regional analysis of female performance in Ukrainian ballet: 90 s of the XX - beginning of the XXI century. (part I: Kyiv and Lviv)]. Kultura i suchasnist, 1, pp.268-273.

\section{ОСОБЕННОСТИ ЖЕНСКОГО БАЛЕТНОГО ИСПОЛНИТЕЛЬСТВА 1970-1980-Х ГГ. (НА ПРИМЕРЕ СЦЕНИЧЕСКОЙ ДЕЯТЕЛЬНОСТИ Т. ЛИТВИНОВОЙ И С. ПРИХОДЬКО)}

\section{Ольга Верховенко}

кандидат искусствоведения; e-mail: olenkaverkhovenko.25@gmail.com; ORCID: 0000-0001-5063-3306

Национальный университет физического воспитания и спорта Украины, Киев, Украина

\section{Аннотация}

Цель исследования - изучить сценические достижения ведущих солисток столичной балетной сцены - Татьяны Литвиновой и Светланы Приходько, успешно работавших на сцене Киевского ГАТОБ им. Т. Шевченко в течение 1970-1980-х годов. Методология работы включает использование следующих методов исследования: общеисторического (с целью изучения исторических процессов, происходивших в художественной сфере Украины на протяжении последней четверти XX в.), историко-культурного (позволяет исследовать динамику развития исполнительской культуры танцовщиков), аналитического (для обработки историографических источников - культурологической, искусствоведческой и театроведческой литературы), системного (с целью систематизации сведений о творческом становлении артистов Киевского ГАТОБ им. Т. Шевченко) и др. Научная новизна публикации заключается в том, что в ней впервые рассмотрены творческие достижения Т. Литвиновой и С. Приходько, связанные с участием танцовщиц в новаторских постановках балетмейстеров последней четверти XX века. Выводы. Путь в большое искусство для Т. Литвиновой и С. Приходько открылся в начале 1970-х гг. с приходом в балетную труппу Киевского ГАТОБ им. Т. Шевченко. Там до конца 1980-х гг. они творили под руководством ведущих балетмейстеров того времени: А. Шекеры, Г. Майорова, В. Литвинова и других постановщиков. Исполнительской манере балерин были одинаково близки как лирические образы (поэзия романтического мира - Одетта-Одилия, Жизель, Мирта, Белая Дама, Сильфида, Полевая русалка), так и партии, наполненные глубоким драматическим звучанием (противоречивый мир человеческих страстей - Кармен, Ольга, Ширин, Фригия, Зарема, Девушка). В число особенных сценических побед танцовщиц вошли престижные премии II Международного конкурса артистов балета в Москве, X Всемирного фестиваля молодежи и студентов в Берлине (Т. Литвинова), Всесоюзного конкурса балетмейстеров и артистов балета в Москве (С. Приходько).

Ключевые слова: Т. Литвинова; С. Приходько; украинский балетный театр; классический танец 


\title{
PECULIARITIES OF WOMEN BALLET PERFORMANCE 1970-1980S. (ON THE EXAMPLE OF STAGE ACTIVITIES OF T. LYTVYNOVA AND S. PRYKHODKO)
}

\section{Olha Verkhovenko}

PhD in Art History; e-mail: olenkaverkhovenko.25@gmail.com; ORCID: 0000-0001-5063-3306

National University of Physical Education and Sport of Ukraine, Kyiv, Ukraine

\begin{abstract}
The purpose of the article is the stage achievements of the leading soloists of the capital's ballet stage - Tatiana Lytvynova and Svetlana Prykhodko, who successfully worked on the stage of Kyiv State Academic Opera and Ballet Theater (SAOBT) named after T. Shevchenko during the 1970s and 1980s. Research methods include the use of the following research methods: general historical (in order to study the historical processes that took place in the artistic environment of Ukraine during the last quarter of the twentieth century), historical and cultural (allowed studying the dynamics of performing dancers' culture), analytical (for historiographical sources are cultural, art and theater literature), system (to systematize information on the artists' creative development of the Kyiv Shevchenko State Theater), etc. Scientific novelty of publication consists in the fact that for the first time the creative works of T. Lytvynova and S. Prykhodko related to their participation in innovative productions of choreographers of the last quarter of the $20^{\text {th }}$ century are considered. Conclusions. The path to great art for T. Lytvynova and S. Prykhodko opened in the early 1970s with the arrival of the ballet troupe of Kyiv State Academic Opera and Ballet Theater (SAOBT) named after T. Shevchenko. There, until the end of the 1980s, they created under the direction of leading choreographers of the time: A. Shekery, G. Mayorov, V. Lytvynov and other directors. Both lyrical images (poetry of the romantic world is Odette-Odile, Giselle, Myrtle, White Lady, Sylphide, Field Mermaid) and parts full of deep dramatic sound (contradictory world of human passions, Carmen, Carmen, Carmen, Omer) were equally close to the performance style of both ballerinas Shyryn, Phrygia, Zarema, Girl). Among the special stage victories of the dancers were the prestigious prizes of the second International Ballet Competition in Moscow, the tenth World Festival of Youth and Students in Berlin (T. Lytvynova), the All-Union Competition of Ballet Masters and Ballet Artists in Moscow (S. Prykhodko).
\end{abstract}

Keywords: T. Lytvynova; S. Prykhodko; Ukrainian Ballet Theater; classical dance 